\title{
Modulation of Force during Locomotion: Differential Action of Crustacean Cardioactive Peptide on Power-Stroke and Return- Stroke Motor Neurons
}

\author{
Brian Mulloney, ${ }^{1}$ Hisaaki Namba, ${ }^{1}$ Hans-Jürgen Agricola, ${ }^{2}$ and Wendy M. Hall ${ }^{1}$ \\ 1Section of Neurobiology, Physiology, and Behavior, University of California Davis, Davis, California 95616-8755, and \\ ²Biologisch-Pharmazeutische Fakultät, Friedrich-Schiller-Universität, D-07743 Jena, Germany
}

Crustacean cardioactive peptide (CCAP) elicited expression of the motor pattern that drives coordinated swimmeret beating in crayfish and modulated this pattern in a dose-dependent manner. In each ganglion that innervates swimmerets, neurons with CCAP-like immunoreactivity sent processes to the lateral neuropils, which contain branches of swimmeret motor neurons and the local pattern-generating circuits.

CCAP affected each of the four functional groups of motor neurons, power-stroke excitors (PSE), return-stroke excitors (RSE), power-stroke inhibitors (PSI), and return-stroke inhibitors (RSI), that innervate each swimmeret. When CCAP was superfused, the membrane potentials of these neurons began to oscillate periodically about their mean potentials. The mean potentials of PSE and RSI neurons depolarized, and some of these neurons began to fire during each depolarization. Both intensity and durations of PSE bursts increased significantly. The mean potentials of RSE and PSI neurons hyperpolarized, and these neurons were less likely to fire during each depolarization. When CCAP was superfused in a low $\mathrm{Ca}^{2+}$ saline that blocked chemical transmission, these changes in mean potential persisted, but the periodic oscillations disappeared.

These results are evidence that CCAP acts at two levels: activation of local premotor circuits and direct modulation of swimmeret motor neurons. The action on motor neurons is differential; PSEs and RSIs are excited, but RSEs and PSIs are inhibited. The consequences of this selectivity are to increase intensity of bursts of impulses that excite power-stroke muscles.

Key words: neuropeptide; pattern generation; crayfish; immunocytochemistry; modulation; neuropil
Crustaceans have paired limbs, called swimmerets, on their abdomen that can propel the animal through the water. Crayfish have four pairs that they use to swim forward. Each swimmeret has its own set of motor neurons that are driven by a local central pattern-generating circuit (Murchison et al., 1993). Both in freeranging animals and in isolated abdominal nerve cords, the swimmeret system at different times can be active or quiet. Active preparations are distinguished by periodic, alternating bursts of impulses in the motor axons that innervate the power-stroke and return-stroke muscles of each swimmeret and by a metachronal coordination of these bursts in axons that innervate different swimmerets (Ikeda and Wiersma, 1964). Quiet preparations do not express these periodic bursts of impulses. Transitions between these states occur spontaneously in isolated preparations and can be triggered by the stimulation of individual command interneurons (Wiersma and Ikeda, 1964; Acevedo et al., 1994) and by the introduction of certain putative neurotransmitters (Mulloney et al., 1987; Braun and Mulloney, 1993; Chrachri and Neil, 1993; Acevedo et al., 1994).

Motor patterns elicited by stimulating different individual command interneurons are remarkably uniform in their temporal structure (Acevedo et al., 1994), which suggests that other parallel neural mechanisms must exist to adjust the details of these

\footnotetext{
Received May 7, 1997; revised June 26, 1997; accepted June 30, 1997.

This work was supported by National Science Foundation Grant IBN-9514889 to B.M. We thank Karen Sigvardt and Masakazu Takahata for reading this manuscript critically.

Correspondence should be addressed to Dr. Brian Mulloney, University of California Davis, Davis, California 95616-8755.

Copyright (C) 1997 Society for Neuroscience $0270-6474 / 97 / 176872-12 \$ 05.00 / 0$
}

patterns so that movements of these limbs produce the forces the animal needs to swim forward effectively. Comparison of the effects of different putative transmitters and modulators is a strategy for discovering how these mechanisms might work. The peptide proctolin and muscarinic agonists of acetylcholine both activate the swimmeret system in quiet preparations but elicit activity limited to a fraction of the range of periods an intact crayfish can express (Mulloney et al., 1987; Braun and Mulloney, 1993). Nicotinic agonists of acetylcholine do not activate quiet preparations but modulate the periods of spontaneously active preparations through almost the full range of periods observed in the intact animal (Mulloney, 1997). These observations suggest that several parallel mechanisms might control the performance of this motor system.

Crustacean cardioactive peptide (CCAP) occurs in neurons in each segmental ganglion of crustaceans and insects (Stangier et al., 1988; Ewer and Truman, 1996). CCAP can both elicit and modulate motor activity in these animals (Gammie and Truman, 1997; Weimann et al., 1997). Axons of interneurons with CCAPlike immunoreactivity (CCAP-IR) run the length of the crayfish ventral nerve cord, and three pairs of neurons with CCAP-IR occur in each ganglion that innervates swimmerets (Trube et al., 1994). However, the physiological roles and sites of action of the CCAP in the swimmerets are undescribed.

We found that CCAP applied to the isolated ventral nerve cord excited the swimmeret system, and processes of neurons with CCAP-IR projected to the lateral neuropils ( $\mathrm{LN}$ ), the anatomical sites of the swimmeret modules. CCAP also modulated bursts of impulses in a way that would increase the force of each powerstroke. Motor neurons that drove power-strokes were excited by 
CCAP, but motor neurons that drove return-strokes were inhibited. There were two aspects of this modulation: CCAP acted directly on swimmeret motor neurons and also acted on the premotor pattern-generating circuit that drives these neurons.

\section{MATERIALS AND METHODS}

Crayfish, Pacifastacus leniusculus, were obtained from local suppliers and kept in aerated freshwater aquaria at $15^{\circ} \mathrm{C}$.

Experiments were performed on isolated abdominal nerve cords. The ventral nerve cord was isolated and pinned out in a SYLGARD-lined dish under crayfish saline. The sheath surrounding each ganglion was removed surgically from the dorsal side to facilitate the diffusion of peptide into the ganglia.

Isolated cords were superfused continuously with aerated saline at a rate of $\sim 2.5 \mathrm{ml} / \mathrm{min}$. The volume of the bath was $3 \mathrm{ml}$. The normal saline solution contained (in mM) $195 \mathrm{NaCl}, 5.36 \mathrm{KCl}, 2.6 \mathrm{MgCl}_{2}, 13.5 \mathrm{CaCl}_{2}$, and 10 Tris-maleate buffer at $\mathrm{pH}$ 7.4. Synaptic input to the motor neurons was blocked with a modified saline that contained $20 \times$ normal $\mathrm{Mg}^{2+}, 1: 5$ normal $\mathrm{Ca}^{2+}$, and 3:5 normal $\mathrm{Na}^{+}$(Sherff and Mulloney, 1996). The solution bathing the preparation was changed by switching it to a different source; the lag between switching the source and the new solution first reaching the bath was $\sim 80 \mathrm{sec}$.

Electrophysiology. The swimmeret motor pattern was recorded extracellularly from the RS and PS branches of N1 from abdominal ganglia 2, 3,4 , and 5 (A2-A5) with stainless steel pin electrodes (Mulloney and Selverston, 1974). Normal swimmeret motor patterns are characterized by cyclic alternation of bursts of impulses in the power-stroke (PS) and return-stroke (RS) motor neurons that innervate each swimmeret. In this species PS axons run in the posterior branch and RS axons run in the anterior branch of each N1.

Intracellular recordings were made with glass microelectrodes and an Axoclamp-2B (Axon Instruments, Foster City, CA) from processes of motor neurons in the LN (Skinner, 1985b) of ganglion A4. Microelectrodes were filled with $2.5 \mathrm{M} \mathrm{KCl}$ and had resistances between 30 and $40 \mathrm{M} \Omega$.

Both extracellular and microelectrode recordings were collected on VCR tape, using a Neuro-Corder 886 (Neurodata Instruments). Recordings were played back later onto a Gould ES1000 electrostatic recorder or transferred to a computer for analysis with pClamp or AxoScope programs (Axon Instruments). When we used AxoScope to display or analyze experiments that had a long time course (e.g., Fig. 5), we reduced the sampling rate of the digitizer by decimating the original recordings with a mini-max protocol to keep the resulting files within reasonable bounds. To illustrate bursts of impulses in these experiments effectively, we integrated them before digitizing the recordings, a procedure that created a low-frequency pulse that survived decimating and that represented the occurrence and intensity of each burst (Mulloney et al., 1987).

Pharmacology. CCAP (8775, Peninsula Laboratories, San Carlos, CA) was dissolved in normal saline or in low $\mathrm{Ca}^{2+}$, high $\mathrm{Mg}^{2+}$ saline and applied to the preparation in the bath. In experiments in which the preparation was spontaneously active, swimmeret motor patterns were recorded first in normal saline. Then the preparation was bathed in selected concentrations of CCAP, and its activity was recorded once it appeared to have reached a new steady state. In experiments in which the preparation was initially quiet, recording began before CCAP was introduced.

Immunocytochemistry. Nerve cords destined for immunocytochemistry were fixed by perfusion with $2 \%$ formaldehyde plus $0.2 \%$ picric acid in PBS, removed, pinned out, and desheathed under cold fixative. Ganglia were incubated with 1:2500 CCAP antiserum (Agricola et al., 1995; Ewer and Truman, 1996). Labeled neurons were visualized with a secondary antibody tagged with HRP and visualized with DAB (Mulloney and Hall, 1990, 1991). Selected ganglia were embedded and sectioned in plastic. Sections were photographed with Nikon Planapochromatic objectives and with Kodak Techpan 120 film.

Quantitative analysis. Modulation of the swimmeret motor pattern was detected by measuring the period, duration, and phase of bursts of impulses recorded from branches of N1 under different conditions. Modulation of the intensity of these bursts of impulses was detected by integrating individual bursts and measuring the area of each integrated burst with a digitizing tablet and the SigmaScan program (Jandel Scientific, San Rafael, CA). This area was proportional both to recent impulse frequency and to impulse amplitude (Mulloney et al., 1987). Descriptive statistics of these parameters were calculated by the PD programs (Mulloney and Hall, 1987) or the SigmaStat program (Jandel).

The probabilities that parameters recorded under different conditions were significantly different were estimated by Student's $t$ tests or ANOVA, using SigmaStat.

\section{RESULTS \\ CCAP excited the swimmeret system and modulated the motor pattern}

When solutions containing CCAP were superfused over quiet preparations of the abdominal nerve cord, the ganglia began to express coordinated swimmeret activity within 15-30 sec after CCAP first reached the bath (Fig. 1A). This excitation was persistent but reversible; production of coordinated bursts persisted as long as the CCAP was present in the bath but stopped within a few minutes when normal saline again was superfused to remove CCAP. Intracellular recordings from individual motor neurons during the introduction of CCAP to the bath revealed that their membrane potentials began to oscillate periodically at approximately the time that impulses began to occur in peripheral nerves (Fig. 1B). With time, these oscillations increased in size, and some of these motor neurons began to fire impulses during each depolarization, in phase with the swimmeret motor pattern.

\section{CCAP modulation was dose-dependent}

When CCAP was applied to spontaneously active preparations, the intensities and durations of PS bursts increased (Fig. 2A). Individual motor units fired more impulses per burst, and new motor units were recruited. To measure changes in intensity of these multiunit bursts, we integrated individual bursts and measured the area of the integrals (Mulloney et al., 1987). The area of the integral is proportional both to impulse frequency and to the size of the impulses, and so increases in this measure reflect both an increase in firing frequency of individual motor axons and the recruitment of new units. Via this measure of burst intensity the threshold concentration was $\sim 0.01 \mu \mathrm{M}$ CCAP, and the response saturated at $\sim 3 \mu \mathrm{M}$ (Fig. $2 B$ ). The $\mathrm{ED}_{50}$ of this modulation was $0.25 \mu \mathrm{M}$ CCAP. The maximum increase in intensity was 2.5 times control, a significant change (ANOVA, $p=0.002$ ). This modulation also was reversed by washing out the CCAP. This threshold is 100-fold higher than the threshold of neurons in the crab stomatogastric ganglion (Weimann et al., 1997). It might simply be that access from the bath to the sites of action of CCAP is more difficult in these large abdominal ganglia than in the stomatogastric ganglion, or there might be differences in the CCAP receptors on these different neurons.

In contrast to burst intensity, neither intersegmental phase nor cycle period were affected by CCAP. Period did increase slightly (Fig. $2 C$ ), but the differences between periods recorded in different concentrations were not statistically significant (ANOVA, $p=$ 0.372).

\section{CCAP selectively increased bursts of impulses in power-stroke excitor (PSE) motor axons}

In some preparations the swimmeret system spontaneously produced motor patterns that included discrete bursts of impulses in peripheral inhibitor motor axons (Davis, 1971) in addition to the bursts in excitatory axons that we commonly observed. There are three return-stroke inhibitor axons (RSI) and two power-stroke inhibitor axons (PSI) that have been identified by GABA immunocytochemistry (Mulloney and Hall, 1990). These inhibitory units normally have been identified in physiological experiments 

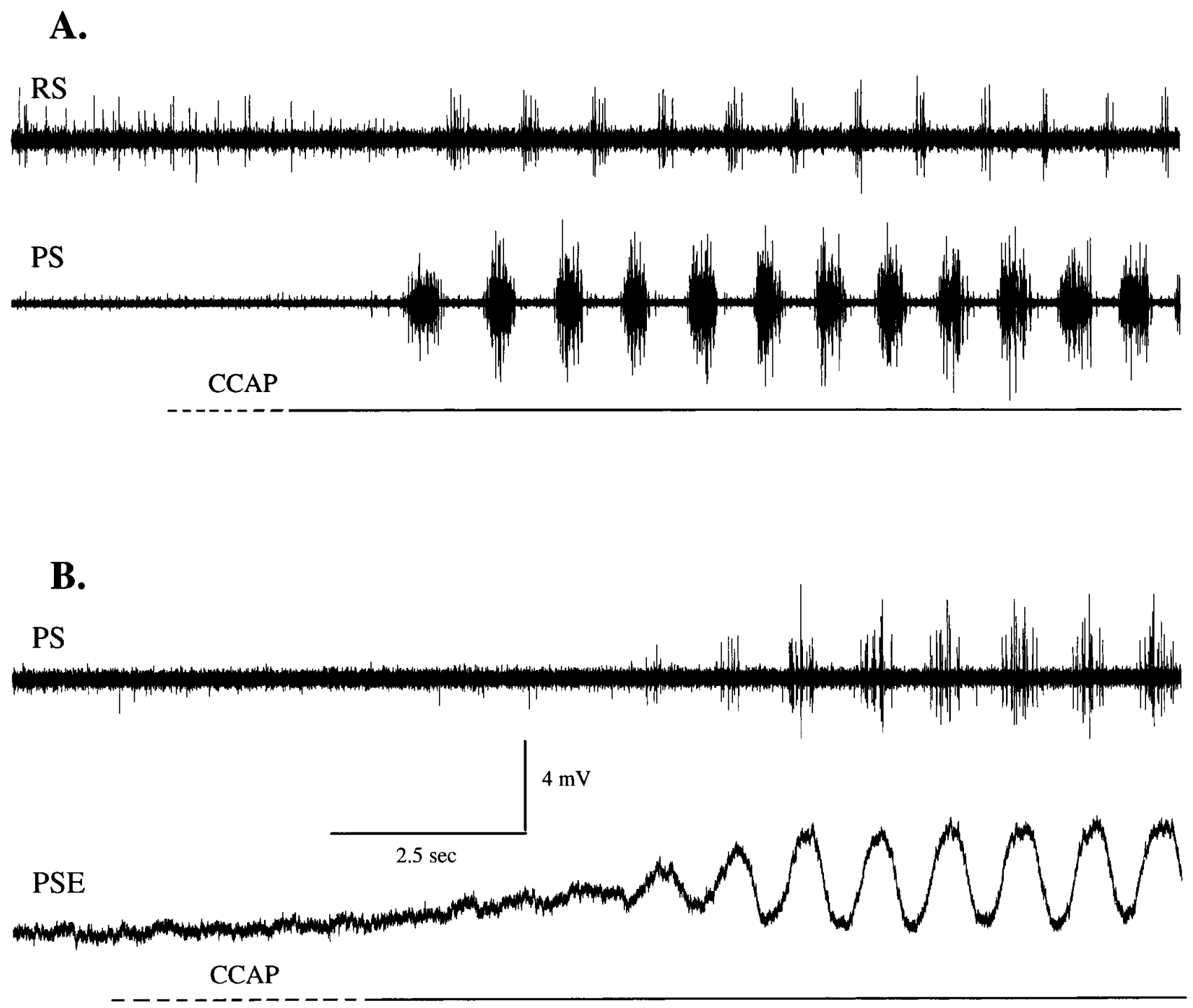

Figure 1. Crustacean cardioactive peptide $(C C A P)$ excited the swimmeret system. $A$, When applied to quiet preparations of the abdominal nerve cord, $C C A P$ elicited expression of coordinated bursts of impulses in nerves that innervate each swimmeret. Bursts of impulses in power-stroke (PS) axons alternated with bursts in return-stroke $(R S)$ axons recorded extracellularly from different branches of the nerve to one swimmeret. $B$, An intracellular recording from a power-stroke excitor motor neuron $(P S E)$ during the transition elicited by $C C A P$. This neuron did not fire impulses during this interval, but other PS units recorded extracellularly fired during each cycle of depolarization. The horizontal line below each section, beginning with a dotted section during which concentration was increasing rapidly, marks the interval when CCAP was present. The membrane potential of PSE at the start of the recording was $-60 \mathrm{mV}$. The time scale is the same for both $A$ and $B$.

by the presence of their axons in the branch of N1 that innervates either power-stroke or return-stroke muscles and by the timing of their bursts of impulses, which occur simultaneously with bursts in axons that excite the antagonistic muscles, and so alternate with bursts in the majority of axons in their own nerve (Davis, 1971; Stein, 1971; Sherff and Mulloney, 1996, 1997). In this series of experiments we did not record bursts of impulses in PSI units often, but these properties allowed us to record PSE, RSE, and RSI bursts simultaneously and to observe that they differed in their responses to CCAP (Fig. 3).

Some preparations produced swimmeret motor patterns spontaneously, and during this spontaneous activity the durations of PSE and RSE bursts were not significantly different (mean duration $\pm \mathrm{SD}: 0.244 \pm 0.023$ and $0.235 \pm 0.023 \mathrm{sec} ; p=0.60)$. In the presence of CCAP, bursts of impulses in PSE motor neurons lasted longer (Fig. 3) and began to overlap RSE bursts. A signif- icant difference between PSE and RSE durations was apparent even at low doses of CCAP. In $0.1 \mu \mathrm{M}$ CCAP, the duration of PSE bursts was $0.368 \pm 0.107 \mathrm{sec}$ (mean $\pm \mathrm{SD})$, but that of RSE bursts was $0.184 \pm 0.033 \mathrm{sec}(t$ test, $p=0.017)$.

Durations of PSE bursts recorded in different concentrations of CCAP were significantly different (ANOVA, $p<0.001$ ). At 3.1 $\mu \mathrm{M}$ CCAP, PSE durations were twice those recorded in saline. Individual PSE motor units fired at higher frequencies during each burst (Fig. $2 A$ ), and new units were recruited.

In contrast, durations of RSE bursts appeared to decrease slightly as CCAP concentrations increased (Fig. 3), but this apparent decrease was not statistically significant (ANOVA, $p=$ 0.367). Durations of RSI bursts (Fig. 3) also were unaffected by increasing concentrations of CCAP (ANOVA, $p=0.387$ ), although impulse frequency in RSI units did increase somewhat as CCAP concentration increased (data not shown). 

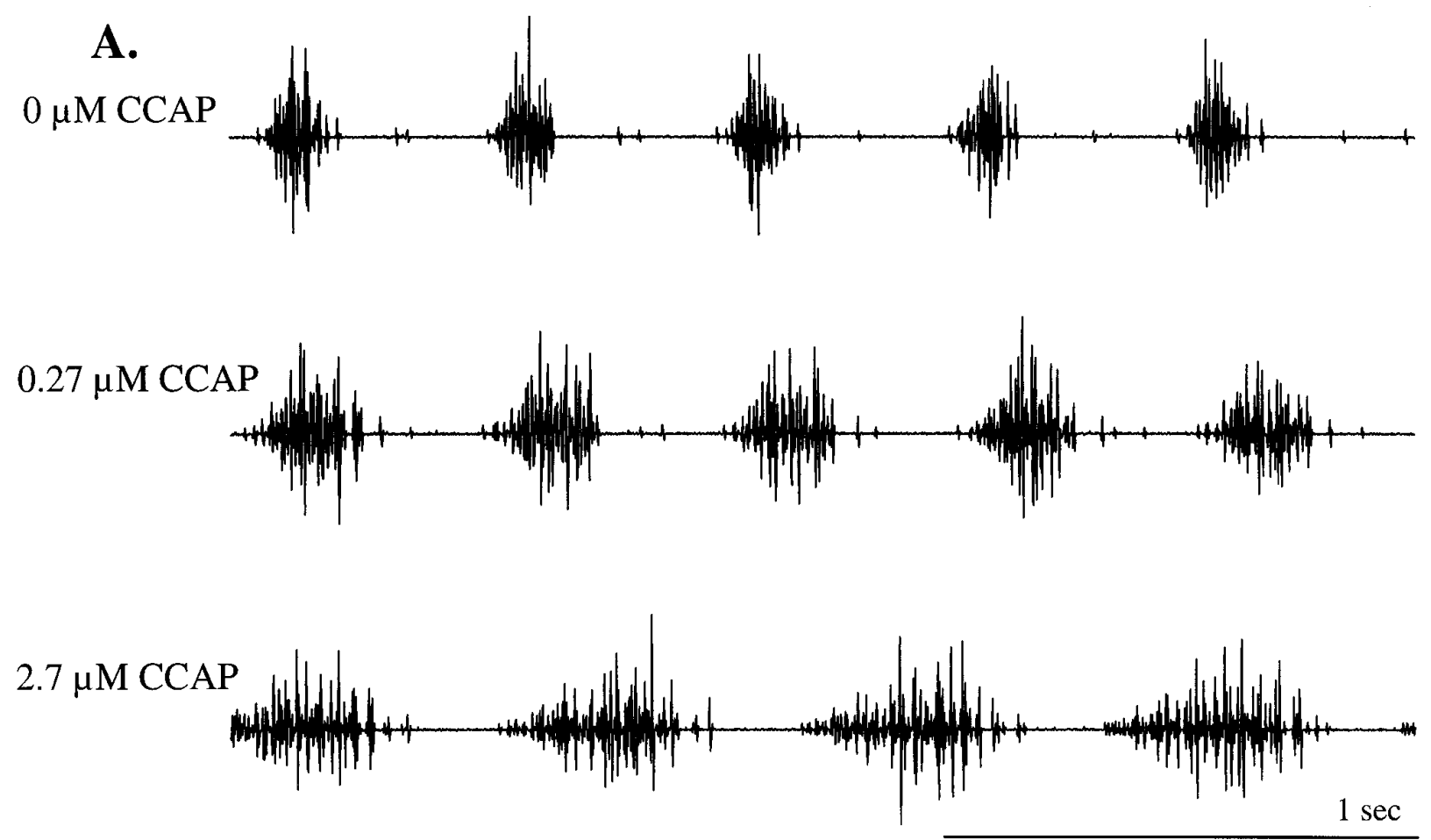

B.

C.
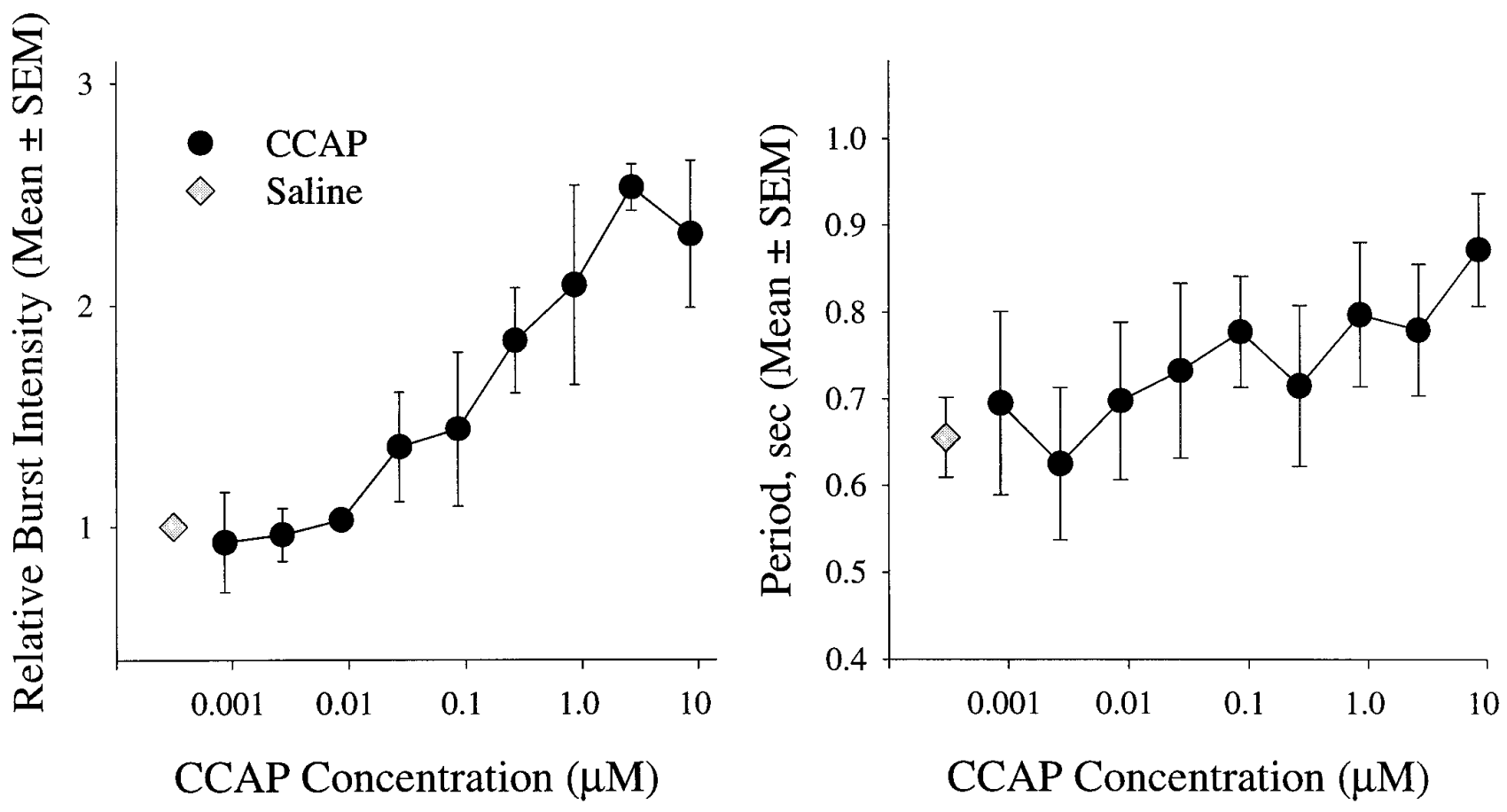

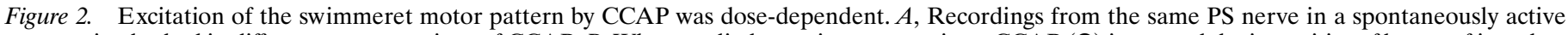

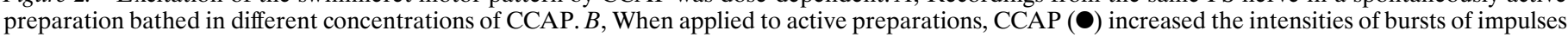

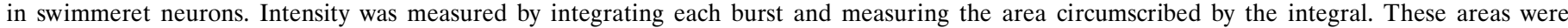

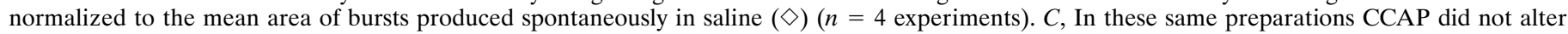
the period significantly. 


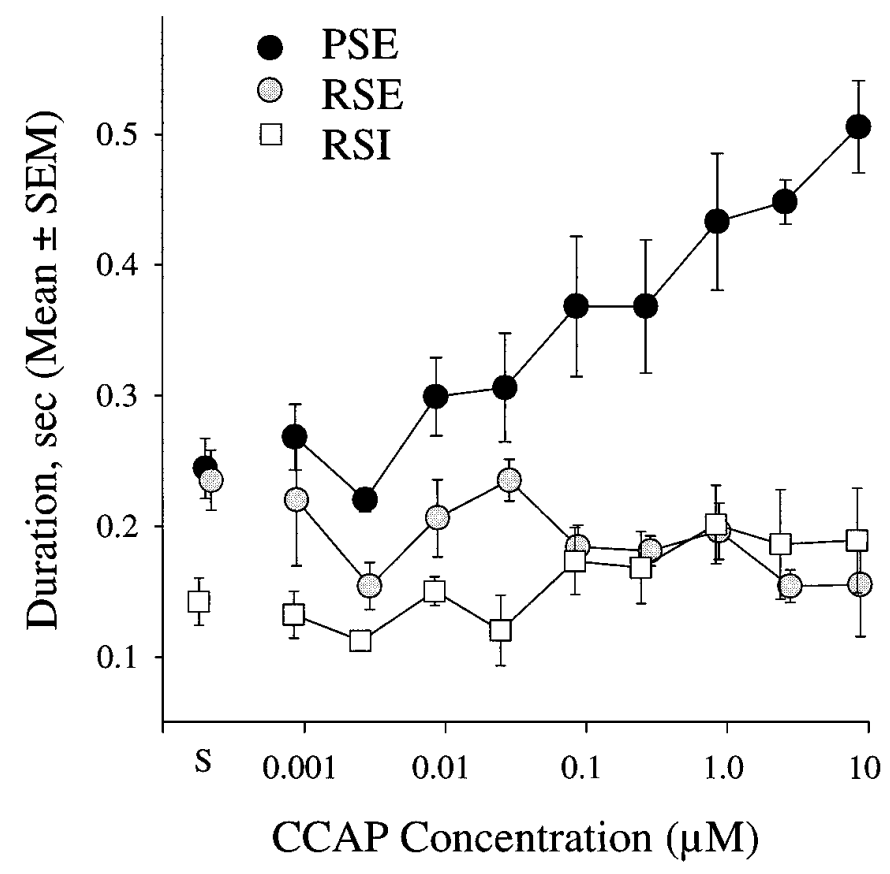

Figure 3. Excitation by CCAP was selective for power-stroke excitor motor neurons (PSE). $S$ identifies data recorded in normal saline.

To summarize, these three functional groups of swimmeret motor neurons responded differently to CCAP: PSEs were strongly excited, RSIs were slightly excited, but RSEs were slightly inhibited. The functional consequence of these changes would be to increase the force of contraction in power-stroke muscles and reduce the force of contraction in their antagonists, the returnstroke muscles, without significantly changing the period of swimmeret beating.

\section{What is the site of action of CCAP in the swimmeret system?}

To test the idea that CCAP might act directly on PSE motor neurons but not on other kinds of swimmeret motor neurons, we examined the projections of neurons with CCAP-like immunoreactivity (CCAP-IR) to the LN of each abdominal ganglion, the loci of the pattern-generating modules that drive these motor neurons (Murchison et al., 1993), to see whether the structural basis for a direct action existed. We also recorded intracellularly from individual motor neurons and applied CCAP both in normal saline and in low $\mathrm{Ca}^{2+}$, high $\mathrm{Mg}^{2+}$ saline to see whether their responses persisted when chemical synaptic transmission had been suppressed (Sherff and Mulloney, 1996).

\section{Three pairs of neurons in each abdominal ganglion showed CCAP-IR}

In each ganglion that innervates swimmerets, three pairs of relatively large interneurons labeled strongly with CCAP antiserum (Fig. 4). In their cell bodies, CCAP-IR was punctate, and the label in the surrounding cytoplasm was faint. The neurites of these neurons appeared to connect with processes running longitudinally in the outer Ventral Lateral Tract (VLT-o) nearby and also to project medially to the Anterior Ventral Commissure (AVC; Skinner, 1985a). The shapes and locations of the cell bodies of these interneurons were the same in each ganglion. Trube et al. (1994) described the same pattern of CCAP-positive neurons in each segmental ganglion of Astacus and Orconectes.
In the connectives anterior and posterior to each ganglion, we observed two clusters of axons (Fig. 4). One cluster occurred near the lateral edge of the connective, in Area 85 (Wiersma and Hughes, 1961). These heavily labeled axons formed a tract connecting adjacent ganglia; this tract continued into the thoracic ganglia. Anterior to A1 (Fig. 4D), this tract contained six axons; posterior to $\mathrm{A} 5$ it contained 10 axons. If these axons project from one of the CCAP-IR neurons in each ganglion, it is probable that their axons project farther than the neighboring ganglia.

A second cluster of larger axons, two per hemiconnective, ran anteriorly near the medial edge in Area 78 (Wiersma and Hughes, 1961). These axons labeled more faintly than did the first group, although they did contain very heavily labeled punctate structures. The position of these axons shifted more dorsally in the connective as they approached the next anterior ganglion, and they appeared to exit the connective through the third nerve of that ganglion.

In some ganglia we also saw one or two additional pairs of tiny neurons. These neurons contained heavily labeled vesicles in a rind surrounding the nucleus, but elsewhere their vesicles were so sparse that we could not follow the neurite from the cell body to the neuropil.

\section{Processes with CCAP-IR projected into each lateral neuropil}

In each ganglion, neural processes in the LNs were intensely labeled by CCAP antiserum. These processes branched repeatedly, contained periodic densely labeled swellings, and seemed to be distributed uniformly within the LN. No axons or cell bodies of swimmeret motor neurons showed any signs of CCAP-IR, although some fine processes that contained periodic labeled boutons ran among the motor axons in the base of N1.

These structural observations are consistent with the idea that interneurons that use CCAP as a transmitter project to each LN and synapse with local components of the swimmeret system.

\section{Different types of swimmeret motor neurons responded differently to CCAP}

When PSE motor neurons in quiet preparations were bathed in CCAP, their membrane potentials depolarized (Table 1) and began to oscillate (Fig. $1 B$ ). As these oscillations increased, the neuron sometimes reached threshold and began to fire impulses during each burst (Fig. $5 A$, and its inset). Resting potentials of PSE neurons and RSE neurons varied, but the amplitudes of these CCAP-induced depolarizations were not correlated with the resting potential of the neuron tested. Linear regression analysis of induced depolarizations with resting potential yielded coefficients of determination, $r^{2}<0.12$.

The responses of RSI motor neurons were more complex; they sometimes showed a minor initial hyperpolarization, followed by a depolarization smaller than that recorded in PSE neurons. Their membrane potentials also oscillated through a wider range of amplitudes as time progressed (Fig. 5D), and they began to fire impulses or bursts of impulses at each cycle.

The membrane potentials of RSE and PSI motor neurons, in contrast, hyperpolarized as they began to oscillate (Table 1; Fig. $5 B, D)$. Their oscillations increased in amplitude as time progressed, but they did not begin to fire impulses. These responses of RSE neurons are consistent with the weakened RSE activity observed in extracellular recordings (Fig. 3) and are consistent with our failure to observe PSI bursts when recording from the peripheral nerves of preparations bathed in CCAP solutions. 

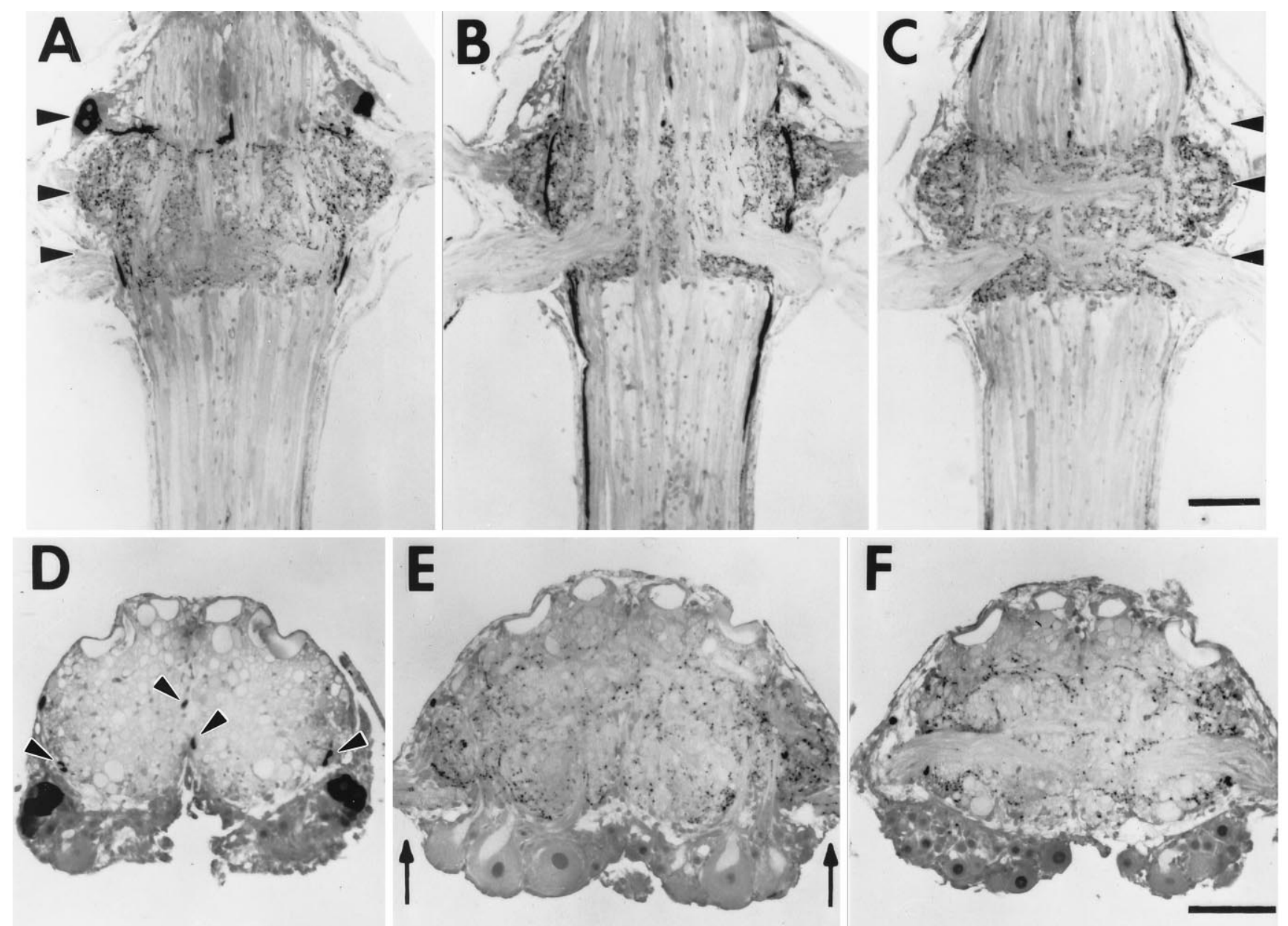

Figure 4. CCAP antiserum labeled processes in the LNs, cell bodies, and interganglionic axons in each ganglion that innervated swimmerets. Photos show $15 \mu \mathrm{m}$ plastic sections of a ganglion labeled with a CCAP antiserum and an HRP-conjugated secondary antibody, visualized with DAB. Each scale bar represents $200 \mu \mathrm{m} ; A-C$ and $D-F$ are the same scales. $A-C$, Frontal sections of an A4 ganglion at three progressively more dorsal levels. In each photograph, anterior is at the top. Arrowheads in $A$ and $C$ mark the planes of three cross sections shown below. $A$ is most ventral and shows the cell bodies of CCAP-IR neurons anterior to N1. $B$, CCAP-IR in processes of axons projecting through the ventral portion of each LN and includes the bases of $\mathrm{N} 1$, the nerve that innervates each swimmeret. $C$, CCAP-IR processes in the LNs anterior to the bases of N2. $D-F$, Cross sections of an A4 ganglion at three levels marked by arrowheads in $A$. In each photograph, dorsal is at the top. $D$, The anterolateral positions of paired cell bodies with CCAP-IR. The pairs of arrowheads mark two sets of axons with CCAP-IR. E, The bases of each N1 (arrows) and processes with CCAP-IR above them in each LN. $F$, The bases of each $\mathrm{N} 2$ and the bundle of CCAP-IR axons in the outer Ventral Lateral Tract passing beneath them.

Table 1. Change of membrane potential $(\mathrm{mV})$ caused by CCAP in each type of swimmeret motor neuron

\begin{tabular}{|c|c|c|c|c|c|c|}
\hline & \multicolumn{3}{|l|}{ Normal saline } & \multicolumn{3}{|c|}{ Low $\mathrm{Ca}^{2+}$, high $\mathrm{Mg}^{2+}$ saline } \\
\hline & $\begin{array}{l}\text { Resting potential } \\
(\text { Mean } \pm \text { SD) }\end{array}$ & $\begin{array}{l}\text { Change } \\
(\text { Mean } \pm \mathrm{SD})\end{array}$ & $n$ & $\begin{array}{l}\text { Steady-state potential } \\
(\text { Mean } \pm \text { SD) }\end{array}$ & $\begin{array}{l}\text { Change } \\
(\text { Mean } \pm \mathrm{SD})\end{array}$ & $n$ \\
\hline PSE & $-59.5 \pm 8.7$ & $5.7 \pm 4.0$ & 11 & $-50.2 \pm 8.2$ & $6.9 \pm 3.0$ & 5 \\
\hline RSE & $-60.7 \pm 6.9$ & $-2.5 \pm 1.5$ & 14 & $-51.2 \pm 7.2$ & $-3.7 \pm 1.7$ & 5 \\
\hline PSI & $-61.2 \pm 6.8$ & $-2.5 \pm 0.7$ & 5 & $-54.0 \pm 10.1$ & $-2.8 \pm 0.5$ & 4 \\
\hline RSI & $-63.5 \pm 6.4$ & $3.3 \pm 1.1$ & 2 & $-53.0 \pm 0.0$ & $3.0 \pm 0.0$ & 1 \\
\hline
\end{tabular}

Because of variability in the perfusion system and uncertainty about the rates of exchange of fluid in the bath, we could not know the moment that CCAP concentrations in the bath reached steady state, but the onset of these changes in the membrane potential of the cell was rapid and was correlated with changes in activity recorded simultaneously from the peripheral nerves. This excitation persisted as long as CCAP was present and was reversible.

\section{CCAP acted directly on the steady-state membrane potentials of swimmeret motor neurons}

We could distinguish two components of the responses of these neurons to CCAP: a steady-state change in membrane potential (Table 1) and a periodic oscillation of potential about this new steady state. To see whether these components were direct responses to CCAP or were the consequence of changes in the 
A.
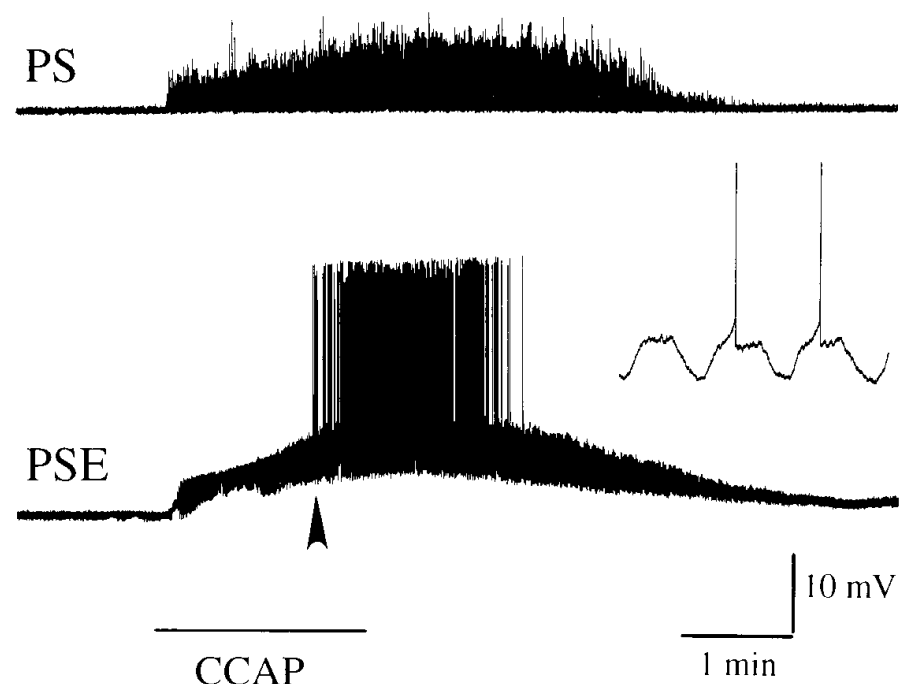

C.

RS

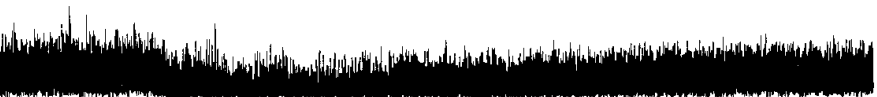

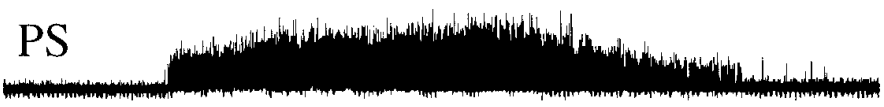

\section{RSE}

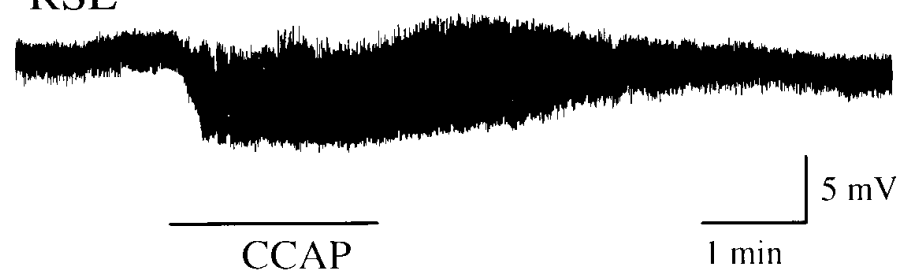

\section{B.}

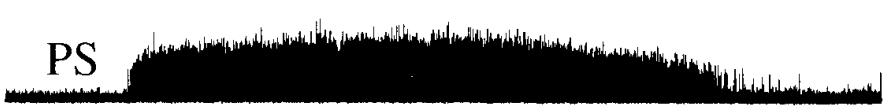

D.

\section{RS}

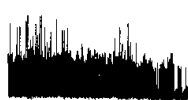

PS

CCAP

$2 \min$

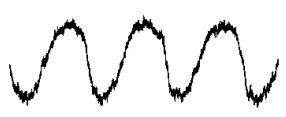

PSI
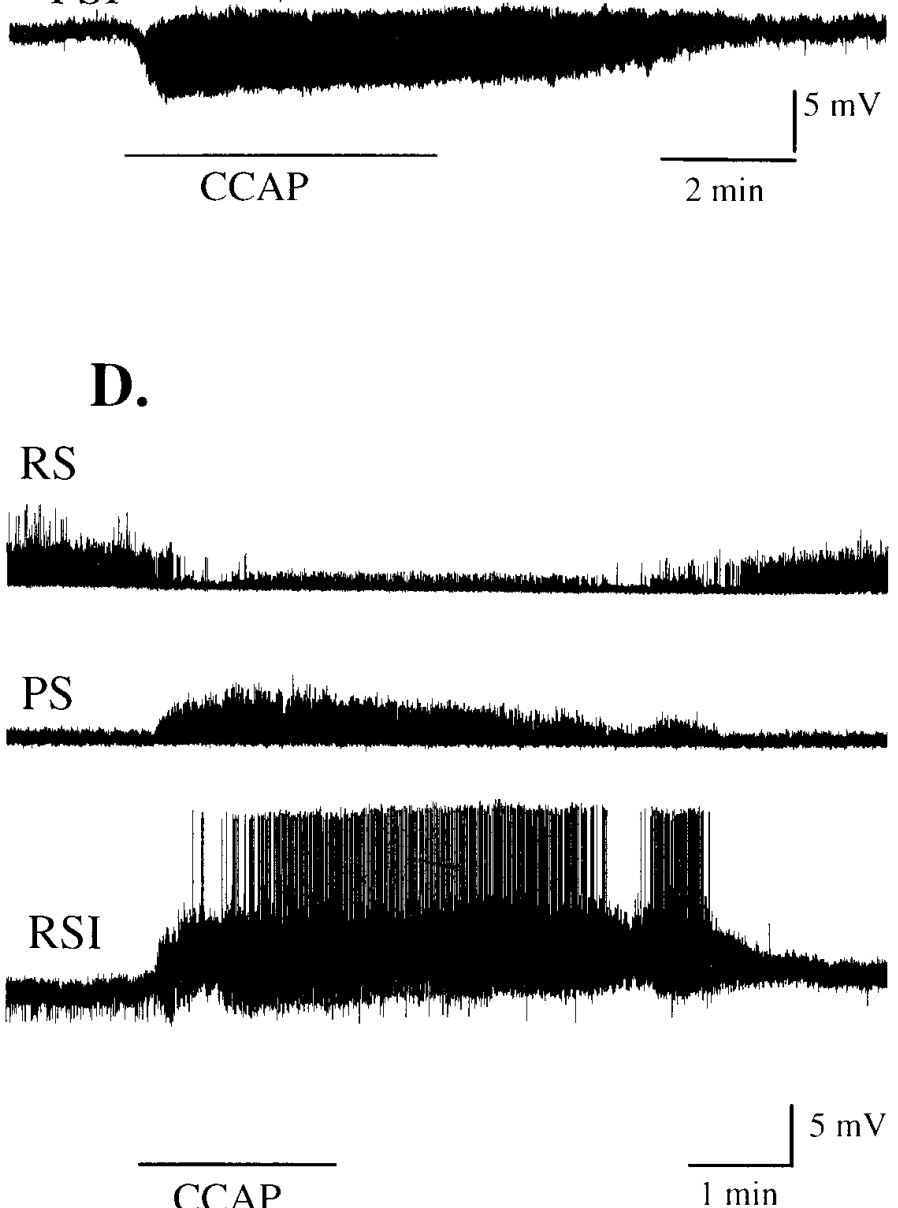

Figure 5. Different functional types of swimmeret motor neuron responded differently to application of $0.5 \mu \mathrm{M}$ CCAP. In these figures extracellularly recorded bursts of impulses have been integrated (see Materials and Methods) and so appear as vertical deflections above the PS or RS traces. $A$, During application of CCAP (horizontal bar), power-stroke (PS) axons began to fire bursts of impulses, and this PSE motor neuron depolarized, began to oscillate, and then began to fire action potentials. The inset shows on an expanded time scale $2.5 \mathrm{sec}$ of this PSE recording that includes the first two of its spikes (arrowhead). The resting potential of this cell was $-60 \mathrm{mV}$. B, C, A power-stroke inhibitor motor neuron (PSI) and a return-stroke excitor motor neuron (RSE) hyperpolarized and began to oscillate in response to CCAP (horizontal bar). The inset in $B$ shows on an expanded time scale 1.8 $\mathrm{sec}$ of this PSI recording (arrowhead). The resting potential of this PSI was $-70 \mathrm{mV}$; of this, RSE was $-57 \mathrm{mV}$. D, Return-stroke inhibitor motor neuron $(R S I)$ depolarized and began to fire action potentials in response to CCAP (horizontal bar). The resting potential of this RSI was -59 mV.

synaptic inputs that drive these motor neurons, we compared the responses of the neurons recorded in normal saline with their responses recorded in low $\mathrm{Ca}^{2+}$, high $\mathrm{Mg}^{2+}$ saline. When isolated preparations that had been active were perfused with low $\mathrm{Ca}^{2+}$, high $\mathrm{Mg}^{2+}$ saline, the swimmeret system became quiet and firing in N1 stopped. The oscillations we had been recording intracellularly from individual motor neurons stopped at the same time, and the membrane potential became unusually quiet (Sherff and Mulloney, 1996). The steady-state potentials of neurons in low $\mathrm{Ca}^{2+}$, high $\mathrm{Mg}^{2+}$ saline were less than their resting potentials in normal saline (Table 1).

Blocking chemical synaptic transmission with low $\mathrm{Ca}^{2+}$, high 

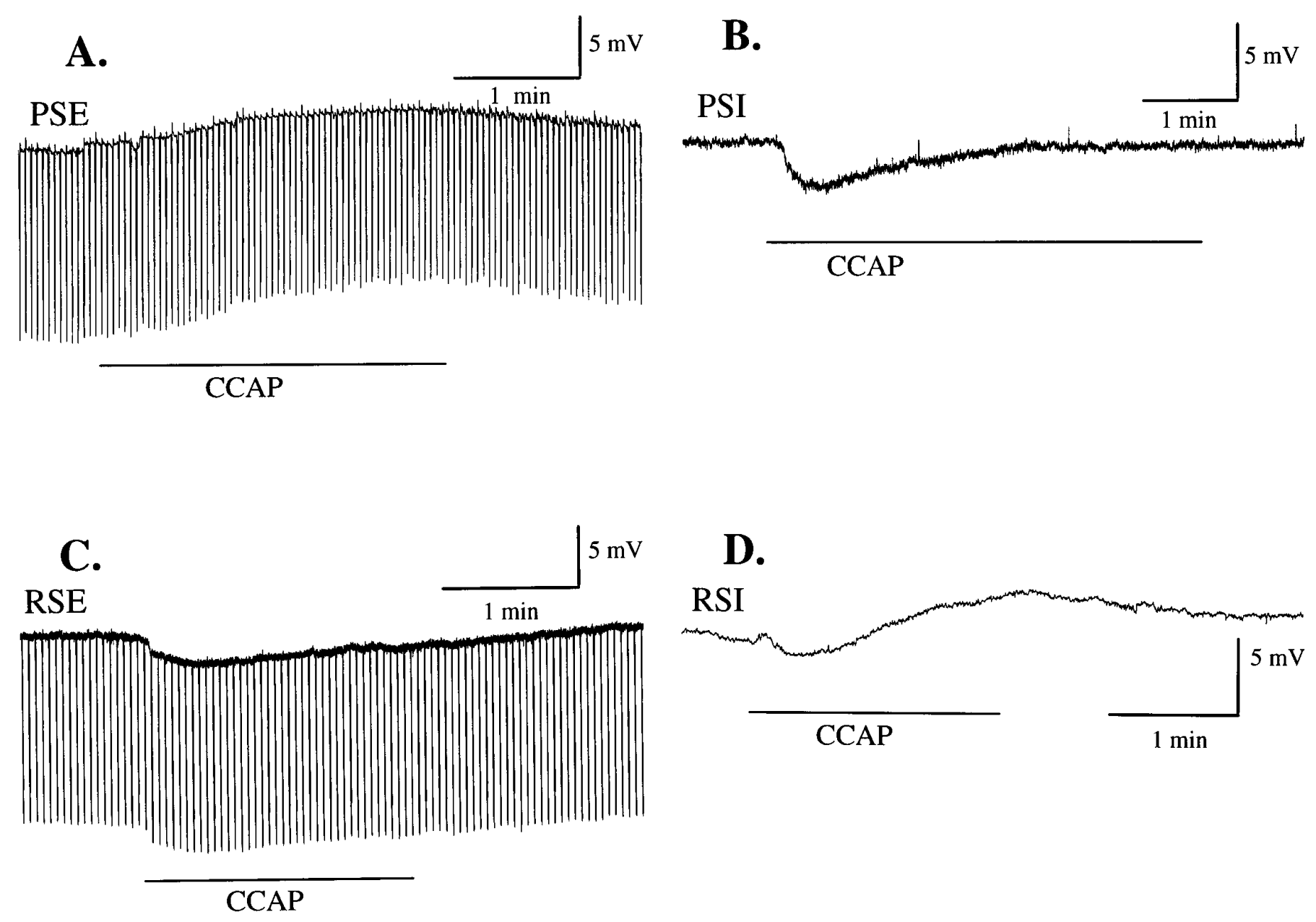

Figure 6. CCAP acted directly on each type of swimmeret motor neuron. Bath application of $0.5 \mu \mathrm{M} \mathrm{CCAP}_{\text {in }}$ low $\mathrm{Ca}^{2+}$, high $\mathrm{Mg}^{2+}$ saline (see Materials and Methods) induced a change in the membrane potential of each neuron. In $A$ and $C$ the input resistance of the neurons was tested periodically with a pulse of hyperpolarizing current. $A$, This PSE neuron depolarized in response to the CCAP (horizontal bar), and its input resistance decreased. At the start of this panel its membrane potential was $-37 \mathrm{mV} . B, C$, A PSI neuron and an RSE neuron hyperpolarized. The membrane potentials at the start were -67 and $-48 \mathrm{mV}$, respectively. The input resistance of this RSE neuron did not change. $D$, This RSI neuron responded with a transient hyperpolarization that reversed to a longer-lasting depolarization when exposed to CCAP (horizontal bar). Its membrane potential at the start was $-52 \mathrm{mV}$.

$\mathrm{Mg}^{2+}$ solution obliterated the periodic oscillations (Fig. 6) but did not affect the steady-state changes of potential caused by CCAP (Table 1); the membrane potentials of each type of motor neuron responded to CCAP presented in low $\mathrm{Ca}^{2+}$ saline as it had to CCAP presented in normal saline (Fig. 6). PSE motor neurons depolarized, and this depolarization persisted as long as the CCAP was present. The membrane potential of RSI responded at first by hyperpolarizing but then depolarized to a new, persistent steady state (Fig. 6D). In contrast, membrane potentials of RSE and PSI motor neurons hyperpolarized (Fig. 6B,C); these hyperpolarizations relaxed at different rates.

The input resistances of these neurons did not change dramatically in response to CCAP. We measured input resistance by periodically injecting small, brief pulses of current through the recording electrode and measuring the resulting changes in membrane potential (Fig. 6). In six cells we detected no change in input resistance when CCAP was introduced in low $\mathrm{Ca}^{2+}$, high $\mathrm{Mg}^{2+}$ saline, although the membrane potential changed (e.g., Fig. $6 C)$. In the two cells in which a change was detectable, CCAP caused a small decrease in input resistance (e.g., Fig. 6A). The mean change was $19 \%$ less than control.

\section{CCAP also activated the pattern-generating circuit in each swimmeret module}

CCAP normally elicited periodic oscillations of membrane potential that were phase-locked with the swimmeret motor pattern (Figs. $1 B, 7$ ), but oscillations did not occur if CCAP was added in low $\mathrm{Ca}^{2+}$, high $\mathrm{Mg}^{2+}$ saline, when chemical synaptic transmission was suppressed (compare Figs. 5, 6). These observations lead us to propose that these oscillations are driven by synaptic transmission from the local pattern-generating circuit to each motor neuron (Mulloney et al., 1993; Murchison et al., 1993) and that the changes in amplitude of these oscillations reflect changes in the strength of that synaptic drive. If this is correct, changes in the amplitudes of these oscillations can be used to monitor changes in the state of the local pattern-generating circuits.

The amplitudes of these oscillations increased both in PSE and RSI neurons, which are excited by CCAP (Fig. 5A,D), and in RSE and PSI neurons, which are inhibited (Fig. $5 B, C$ ). In quiet preparations intracellular recordings from different types of motor neurons revealed that these oscillations started and grew in size over many cycles as CCAP solutions replaced the saline in the 

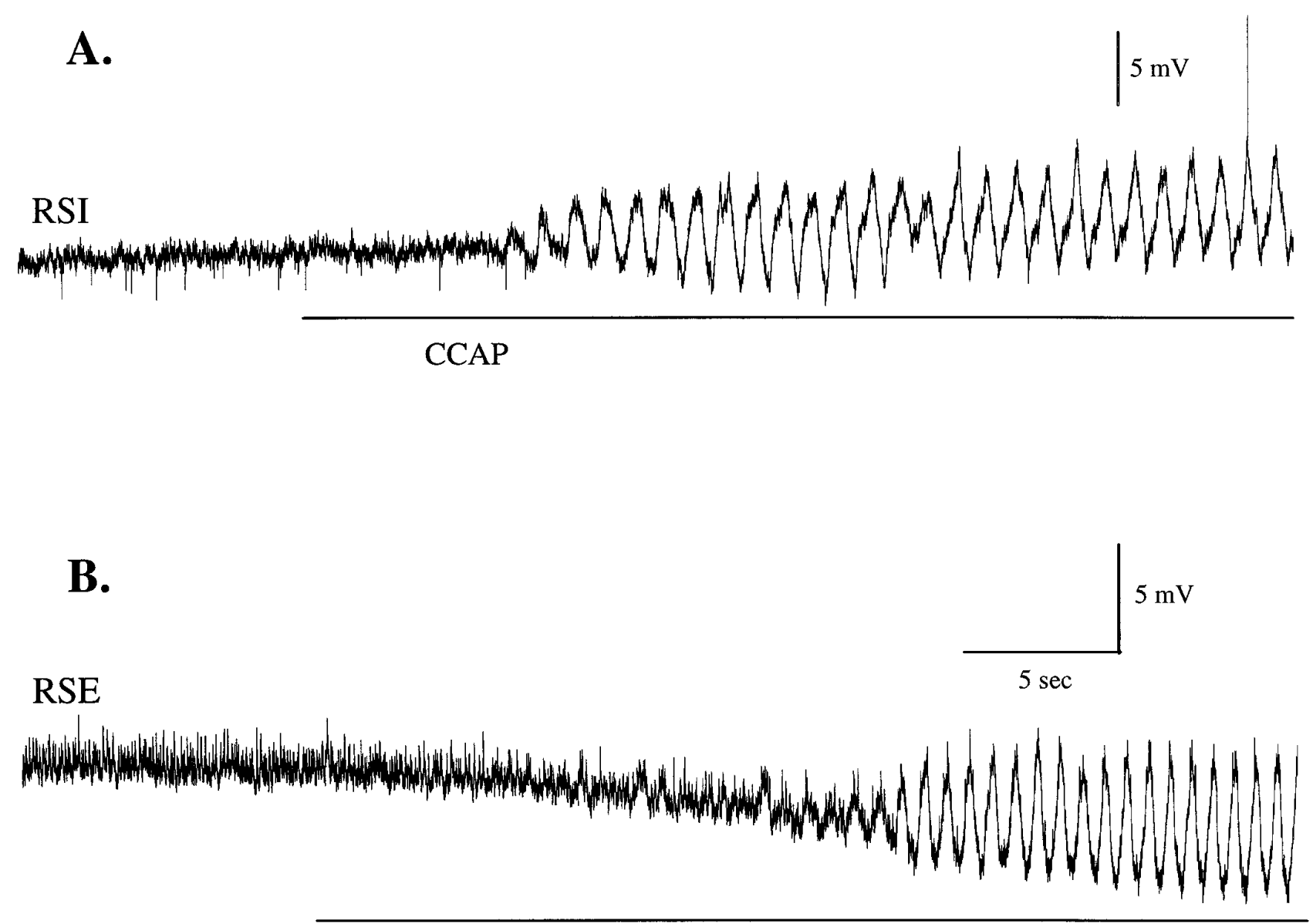

\section{CCAP}

Figure 7. CCAP elicited periodic oscillations of membrane potential from swimmeret neurons. The time at which CCAP first reached the swimmeret system was measured from the first changes in simultaneous extracellular recordings from the same ganglia (data not shown). A, An RSI motor neuron began to oscillate periodically after CCAP reached the bath and on its 26th oscillation fired an action potential. Later in this experiment this neuron fired more than one impulse during each depolarization. $B$, In a different preparation an RSE motor neuron first hyperpolarized and then began to oscillate as CCAP concentration rose. At the start of these figures, the membrane potentials of this RSI and RSE were -59 and $-53 \mathrm{mV}$, respectively. The same time calibration applies to $A$ and $B$.

bath (Figs. $1 B, 7)$. In some recordings the characteristic changes in steady-state membrane potential (Table 1) began before any oscillations appeared (e.g., Figs. $1 B, 7 B$ ). Depolarizations of antagonist motor neurons occur during opposite phases of each cycle, but amplitudes of oscillations increase in all types of motor neurons, so CCAP cannot be working only by biasing the output of the circuit toward PS excitation. Instead, it changes the state of inactive pattern-generating circuits so that they begin to oscillate and increases the strength of their synaptic drive to both PS and RS components.

During some experiments (Table 2) after the system had begun to respond to CCAP, the motor pattern switched abruptly to an unusual state: PSE firing was modulated but virtually continuous, RSI bursts were vigorous, but all RSE and PSI units were silent (Fig. 8B). During these RS-suppressed episodes the periodic large hyperpolarization of PSE neurons that sculpted their bursts of impulses disappeared.

The absence of the periodic inhibition is particularly striking in intracellular recordings. In one example of this phenomenon we compared activity of a PSE neuron during a spontaneous bout of activity that occurred before CCAP was introduced (Fig. 8A) with its activity once excitation by CCAP had reached steady state

\begin{tabular}{lcl}
\hline $\begin{array}{l}\text { Table 2. Relative frequencies of RS-suppressed activity and normal } \\
\text { activity induced by } \mathbf{0 . 5} \boldsymbol{\mu} \mathbf{M} \text { CCAP in each type of swimmeret motor } \\
\text { neuron }\end{array}$ \\
\begin{tabular}{lcl} 
Neuron & Only normal $^{a}$ & RS-suppressed \\
\hline PSE & $8 / 11$ & $3 / 11$ \\
RSE & $10 / 14$ & $4 / 14$ \\
PSI & $3 / 5$ & $2 / 5$ \\
RSI & $2 / 2$ & $0 / 2$
\end{tabular} \\
\hline
\end{tabular}

${ }^{a}$ Number of neurons that showed this activity/all neurons of this type observed.

(Fig. $8 B$ ) and with its activity during the final stages of washing (Fig. $8 C$ ). During the CCAP interval (Fig. $8 B$ ) the periodic hyperpolarization of the PSE neuron failed. The PSE remained depolarized and fired long bursts with brief interruptions and RSI units fired vigorous periodic bursts, but all RSE units were silent during this time; the return-stroke component of the normal motor pattern was silenced, and the local module seemed to be locked in the power-stroke phase. In other experiments with RSE motor neurons we observed that their membrane potentials remained hyperpolarized, whereas PSEs were active in the mode illustrated in Figure $8 B$ (data not shown). 

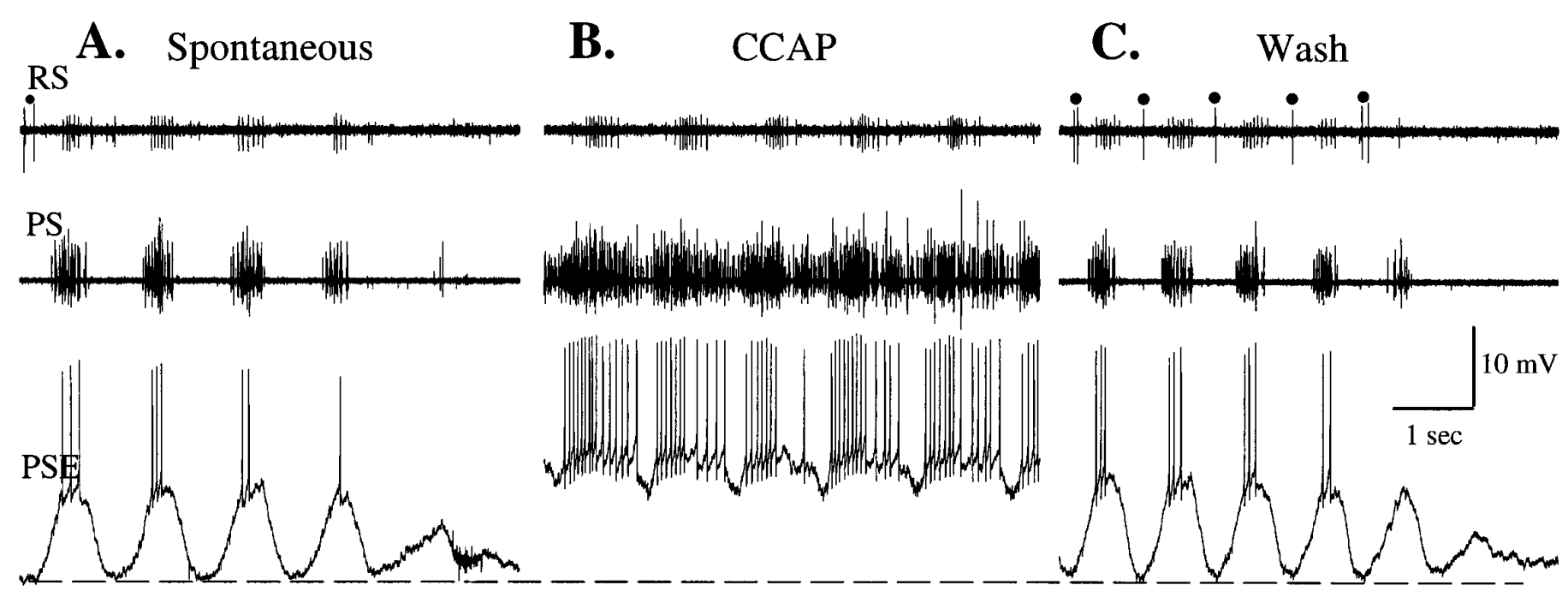

Figure 8. A comparison of spontaneous oscillations and CCAP-evoked oscillations of membrane potential in a PSE motor neuron. PS, RS, Extracellular recordings of activity in the PS and RS branches of the swimmeret nerve. $A$, The end of a spontaneous bout of swimmeret activity that occurred before bath application of CCAP. Simultaneous bursts of impulses in PSE and RSI units alternated with impulses in a few RSE units $(\bullet)$. Periodic depolarization and firing of the PSE neuron ceased as the bout ended. $B$, Activity of the same PSE neuron once bath-applied $0.5 \mu \mathrm{M}$ CCAP had reached steady state. The large periodic hyperpolarizations that occurred in $A$ and in the early stages of the response to CCAP were missing here (see Results). $C$, The last of the activity elicited by CCAP, recorded during the washout of CCAP. Periodic impulses in RSE units $(\bullet)$ coordinated with periodic hyperpolarizations of PSE had reappeared. Dotted line marks the resting potential of this PSE neuron, $-63 \mathrm{mV}$.

In every case in which we observed these RS-suppressed motor patterns, the initial stages of excitation included normal bouts of alternating depolarization and hyperpolarization, and these returned as CCAP was washed out. Each of these experiments used $0.5 \mu \mathrm{M}$ CCAP, a higher concentration than the $\mathrm{ED}_{50}$ (see Fig. $2 B)$. We did not observe this phenomenon during experiments that used lower concentrations of CCAP. Most preparations did not respond this way to CCAP (Table 2), but we did observe it while recording from PSE, RSE, and PSI motor neurons.

\section{DISCUSSION}

CCAP is a cyclic nonapeptide that occurs in the CNS and neurohemal organs of crustaceans and insects (Stangier et al., 1988; Ewer and Truman, 1996). In segmental ganglia of crayfish, three or more pairs of neurons occur that have CCAP-IR (Trube et al., 1994), and in the ganglia that innervate swimmerets these neurons are particularly apparent. The cell body of each swimmeret motor neuron sends its neurite into the LN (Mulloney et al., 1990; Sherff and Mulloney, 1997), where it branches profusely. Our immunocytochemical study found that CCAP-IR neurons projected to each LN (see Fig. 4) and there branched repeatedly. These branches formed periodic densely labeled swellings and seemed to permeate the whole LN. In proctolinergic neurons in these same neuropils, varicosities like these are known from electron microscopy to be synapses (Acevedo et al., 1994). Although further physiological and structural study of CCAP-IR cells is needed to determine which ones act directly on the swimmeret system, this structural evidence would be expected if either the CCAP-IR neurons in each ganglion or the CCAP-IR intersegmental axons innervated targets in each swimmeret module.

\section{CCAP affects the swimmeret system at more than one level}

Swimmeret motor neurons responded directly to bath-applied CCAP in ways that would increase the strength of power-stroke movements relative to return-stroke movements. Both PSE and RSI motor neurons depolarized, bringing them closer to threshold (see Figs. 5, 6). RSE and PSI neurons hyperpolarized and were inhibited by this hyperpolarization (see Figs. 5, 6). These responses might be elicited normally by CCAP released in each $\mathrm{LN}$ from interneurons for which the processes synapse with these motor neurons (see Fig. 4). The consequences of these responses would be to strengthen selectively the stimulus to each PS muscle but to weaken the stimulus to each RS muscle (cf. Weimann et al., 1997).

The observation that the magnitudes of these different steadystate responses to CCAP were unaffected by blocking synaptic transmission (see Table 1) suggests that different swimmeret motor neurons either have different CCAP receptors or have their receptors linked to different membrane currents. When synaptic input was blocked, the hyperpolarizations of RSE and PSI neurons relaxed at different rates, something that was not apparent in normal saline. These relaxations might be attributable to desensitization of CCAP receptors or to the slower development of an inward current gated by CCAP.

Swimmeret pattern-generating interneurons also responded to CCAP. The local circuit in each $\mathrm{LN}$ that produces alternating bursts of impulses in antagonistic motor neurons (Murchison et al., 1993) includes unilateral nonspiking local interneurons for which the branches are restricted mainly to one LN and that drive either PS or RS phases of the activity that controls the swimmeret (Paul and Mulloney, 1985a,b). CCAP bath-applied to quiet preparations elicited periodic oscillations of membrane potential in swimmeret motor neurons (see Figs. 1, 5, 7) and increased amplitudes of these oscillations in active preparations. We think these oscillations are not intrinsic to each motor neuron but, rather, are caused by graded release of transmitter from these local interneurons (Burrows and Siegler, 1978; Burrows, 1979; Nagayama et al., 1983, 1984; Paul and Mulloney, 1985a,b; Siegler, $1985)$ for three reasons. These oscillations are coordinated in the 
entire set of motor neurons that innervate one swimmeret and drive coordinated bursts of impulses in functional synergists when the system is active. Blocking synaptic transmission with low $\mathrm{Ca}^{2+}$ saline eliminated these oscillations (compare Figs. 5, 6; also see Sherff and Mulloney, 1996), but blocking sodium currents with tetrodotoxin did not eliminate oscillations coordinated within each LN (Murchison et al., 1993). Synaptic connections between swimmeret motor neurons are too weak and too sparse to couple periodic oscillations (Sherff and Mulloney, 1996). In this light, the development of coordinated firing in PS and RS neurons (see Fig. $1 A$ ) and the simultaneous development of periodic oscillations in individual motor neurons (see Figs. $1 B, 7$ ) are evidence that CCAP also acted on local pattern-generating interneurons in each swimmeret module.

\section{Modulation by CCAP, compared with other putative transmitters}

CCAP is one of three putative transmitters that excite the swimmeret system in similar ways. Proctolin, a pentapeptide, and acetylcholine in muscarinic pathways also elicit swimmeret activity from quiet preparations (Mulloney et al., 1987; Braun and Mulloney, 1993; Chrachri and Neil, 1993; Acevedo et al., 1994). The activity elicited by these three has the same intersegmental phase as does spontaneous activity, and the periods of the motor patterns they elicit are restricted to a narrow range (see Fig. $2 C$; Braun and Mulloney, 1993). Each of these compounds occurs in abdominal ganglia and has local sites of action there on the swimmeret system (Acevedo et al., 1994; Braun and Mulloney, 1995). Red pigment concentrating hormone (RPCH), another putative neurotransmitter in crustaceans, modulates both period and burst duration simultaneously but cannot elicit expression of the swimmeret motor pattern from quiet preparations. As RPCH concentrations rise, PS bursts get longer, and periods increase (Sherff and Mulloney, 1991). Although they are not identical in their actions, both RPCH and CCAP bias the output of the system toward dominance by power-stroke activity.

From this comparison it seems that CCAP, proctolin, and the muscarinic pathway provide mechanisms for activating the swimmeret system. Because the range of periods they elicit overlaps, perhaps they operate via a common cellular mechanism.

Acetylcholine in nicotinic pathways is quite different; it does not activate the swimmeret system, but it can modulate burst durations and periods of active systems in a coordinated way, without changing either intrasegmental or intersegmental phase. Nicotinic mechanisms modulate the period of swimmeret activity through the full range observed in freely moving animals and do not bias the output toward either power-stroke or return-stroke (Braun and Mulloney, 1993; Mulloney, 1997).

\section{Interpretations of changes in the periodic oscillations of the membrane potential of a motor neuron}

We interpret the appearance and disappearance of periodic oscillations that drive bursts of impulses in these neurons as evidence of activity in the premotor pattern-generating circuit (see above). Changes in the amplitudes of these oscillations are signs of changes in presynaptic transmitter release and a window into the workings of the premotor circuit. When CCAP is introduced, the amplitude of these oscillations grows in both PSE and RSE neurons (see Fig. 5). The membrane potentials of these antagonist neurons oscillate in antiphase, so it is likely that different interneurons that have either PSE or RSE neurons as targets simultaneously increase transmitter release. Several mechanisms might account for this coordinated modulation of release. The premotor interneurons all might be depolarized and so brought into a range of potentials in which small changes in potential have a larger impact on release (Burrows and Siegler, 1978; Burrows, 1979; Blight and Llinás, 1980). Alternatively, CCAP might modulate currents in these premotor neurons that make their own membrane excursions larger (Raper, 1979; Golowasch and Marder, 1992) and so cause larger fluctuations in the amounts of transmitter released. A third alternative would be explicit modulation of transmitter release from the presynaptic neurons without changing their own steady-state potentials or their own oscillations (Johnson and Harris-Warrick, 1990; Mulloney, 1991; Dickinson et al., 1993; Johnson et al., 1995).

We think that the RS-suppressed motor patterns we sometimes observed (e.g., Fig. 8) resulted from a failure of mechanisms that usually promote alternation of antagonists in the premotor circuit (Sharp et al., 1996; Skinner et al., 1997). Consider the presynaptic circuit as a two-part half-center oscillator; this aberrant state would result when the "power-stroke half" persistently inhibits the "return-stroke half," either because it fails to release the RS half or because the RS half fails to escape from its inhibition (Perkel and Mulloney, 1974; Skinner et al., 1994). Because we observed it while recording from PSE, RSE, and PSI neurons, RS-suppressed activity cannot be attributed to gating of one output pathway from a pattern generator that meanwhile continued to operate normally. We think that the absence of periodic inhibition of PSE units reflects an altered mode of operation of the local pattern-generating circuit caused by the dose of CCAP and that these periodic graded hyperpolarizations of PSE motor neurons can be used to monitor the activity of premotor interneurons in the local pattern-generating circuit.

\section{Behavioral consequences of selective increases in power-stroke intensity}

In mechanical terms each swimmeret is an oar that can make a power-stroke and then return to its starting position. The thrust that propels a crayfish when it is swimming forward comes from the contraction of power-stroke muscles working on the lever that is the swimmeret. More impulses per PSE burst would cause power-stroke muscles to contract more forcefully during each stroke (Atwood, 1976; Weimann et al., 1997). More firing by RSI neurons both would reduce the amounts of transmitter released by RSE neurons that innervate the same muscles and would accelerate the relaxation of these return-stroke muscles. The combination of these changes would increase the force of each stroke without significantly changing their frequency. We predict that, when CCAP is present, the system would produce powerstroke movements stronger than those produced in its absence but with the same period and phase relative to the return-stroke as it normally would do.

\section{REFERENCES}

Acevedo LD, Hall WM, Mulloney B (1994) Proctolin and excitation of the crayfish swimmeret system. J Comp Neurol 345:612-627.

Agricola H-J, Bräunig P, Meissner R, Nauman W, Wollweber L, Davis N (1995) Colocalization of allostatin-like immunoreactivity with other neuromodulators in the CNS of Periplaneta americana. In: Learning and memory (Elsner N, Menzel R, eds), p 616. Stuttgart: Thieme Verlag.

Atwood HL (1976) Organization and synaptic physiology of crustacean neuromuscular systems. Prog Neurobiol 7:291-391.

Blight AR, Llinás R (1980) The non-impulsive stretch-receptor complex of the crab: a study of depolarization release coupling at a tonic sensorimotor synapse. Philos Trans R Soc Lond [Biol] 290:219-276. 
Braun G, Mulloney B (1993) Cholinergic modulation of the swimmeret system in crayfish. J Neurophysiol 70:2391-2398.

Braun G, Mulloney B (1995) Coordination in the crayfish swimmeret system: differential excitation causes changes in intersegmental phase. J Neurophysiol 73:880-885.

Burrows M (1979) Graded synaptic interactions between local premotor interneurons of the locust. J Neurophysiol 42:1108-1123.

Burrows M, Siegler MVS (1978) Graded synaptic transmission between local interneurons and motor neurons in the metathoracic ganglion of the locust. J Physiol (Lond) 285:231-256.

Chrachri A, Neil DM (1993) Interaction and synchronization between two abdominal motor systems in crayfish. J Neurophysiol 69:1373-1383.

Davis WJ (1971) Functional significance of motoneuron size and soma position in swimmeret system of the lobster. J Neurophysiol 34:274-288.

Dickinson PS, Mecsas C, Hetling J, Terio K (1993) The neuropeptide red pigment concentrating hormone affects rhythmic pattern generation at multiple sites. J Neurophysiol 69:1475-1483.

Ewer J, Truman JW (1996) Increases in cyclic $3^{\prime}, 5^{\prime}$-guanosine monophosphate (cGMP) occur at ecdysis in an evolutionarily conserved crustacean cardioactive peptide-immunoreactive insect neuronal network. J Comp Neurol 370:330-341.

Gammie SC, Truman JW (1997) Neuropeptide hierarchies and the activation of sequential motor behaviors in the hawkmoth, Manduca sexta. J Neurosci 17:4389-4397.

Golowasch J, Marder E (1992) Proctolin activates an inward current whose voltage dependence is modified by extracellular $\mathrm{Ca}^{2+}$. J Neurosci 12:810-817.

Ikeda K, Wiersma CAG (1964) Autogenic rhythmicity in the abdominal ganglion of the crayfish: the control of swimmeret movements. Comp Biochem Physiol 12:107-115.

Johnson BR, Harris-Warrick RM (1990) Aminergic modulation of graded synaptic transmission in the lobster stomatogastric ganglion. J Neurosci 10:2066-2076.

Johnson BR, Peck JH, Harris-Warrick RM (1995) Distributed amine modulation of graded chemical transmission in the pyloric network of the lobster stomatogastric ganglion. J Neurophysiol 74:437-452.

Mulloney B (1991) Circuit dynamics and the strength of synapses. Curr Biol 1:108-110.

Mulloney B (1997) A test of the excitability-gradient hypothesis in the swimmeret system of crayfish. J Neurosci 17:1860-1868.

Mulloney B, Hall WM (1987) The PD programs: a method for the quantitative description of motor patterns. J Neurosci Methods 19:47-59.

Mulloney B, Hall WM (1990) GABAergic neurons in the crayfish nervous system: an immunocytochemical census of the segmental ganglia and stomatogastric system. J Comp Neurol 291:383-394.

Mulloney B, Hall WM (1991) Neurons with histamine-like immunoreactivity in the segmental and stomatogastric nervous system of the crayfish, Pacifastacus leniusculus, and the lobster, Homarus americanus. Cell Tissue Res 266:197-207.

Mulloney B, Selverston AI (1974) Organization of the stomatogastric ganglion of the spiny lobster. I. Neurons driving the lateral teeth. J Comp Physiol [A] 91:1-32.

Mulloney B, Acevedo LD, Bradbury AG (1987) Modulation of the crayfish swimmeret rhythm by octopamine and the neuropeptide proctolin. J Neurophysiol 58:584-597.

Mulloney B, Acevedo LD, Chrachri A, Hall WM, Sherff CM (1990) A confederation of neural circuits: control of swimmeret movements by a modular system of pattern generators. In: Frontiers in crustacean neurobiology (Wiese K, Krenz WD, Tautz J, Reichert H, Mulloney B, eds), pp 439-447. Basel: Birkhauser Verlag.

Mulloney B, Murchison D, Chrachri A (1993) Modular organization of pattern-generating circuits in a segmental motor system: the swimmerets of crayfish. Semin Neurosci 5:49-57.

Murchison D, Chrachri A, Mulloney B (1993) A separate local patterngenerating circuit controls the movements of each swimmeret in crayfish. J Neurophysiol 70:2620-2631.

Nagayama T, Takahata M, Hisada M (1983) Local spikeless interaction of motoneuron dendrites in the crayfish, Procambarus clarkii. J Comp Physiol [A] 152:335-345.

Nagayama T, Takahata M, Hisada M (1984) Functional characteristics of local non-spiking interneurons as the pre-motor elements in crayfish. J Comp Physiol [A] 154:499-510.

Paul DH, Mulloney B (1985a) Nonspiking local interneuron in the motor pattern generator for the crayfish swimmeret. J Neurophysiol 54:28-39.

Paul DH, Mulloney B (1985b) Local interneurons in the swimmeret system of the crayfish. J Comp Physiol [A] 156:489-502.

Perkel DH, Mulloney B (1974) Motor pattern production in reciprocally inhibitory neurons exhibiting postinhibitory rebound. Science 185:181-183.

Raper J (1979) Non-impulse mediated synaptic transmission during the generation of a cyclic motor program. Science 205:304-306.

Sharp AA, Skinner FK, Marder E (1996) Mechanisms of oscillation in dynamic clamp constructed two-cell half-center circuits. J Neurophysiol 76:867-883.

Sherff CM, Mulloney B (1991) Red pigment concentrating hormone is a modulator of the crayfish swimmeret system. J Exp Biol 155:21-35.

Sherff CM, Mulloney B (1996) Tests of the motor neuron model of the local pattern-generating circuits in the swimmeret system. J Neurosci 16:2839-2859.

Sherff CM, Mulloney B (1997) Passive properties of swimmeret motor neurons. J Neurophysiol, in press.

Siegler MVS (1985) Nonspiking interneurons and motor control in insects. Adv Insect Physiol 18:249-304.

Skinner FK, Kopell N, Marder E (1994) Mechanisms for oscillation and frequency control in reciprocally inhibitory model neural networks. J Comput Neurosci 1:69-88.

Skinner FK, Kopell N, Mulloney B (1997) How does the crayfish swimmeret system work? Insights from nearest neighbor coupled oscillator models. J Comput Neurosci 4:151-160.

Skinner K (1985a) The structure of the fourth abdominal ganglion of the crayfish, Procambarus clarkii. I. Tracts in the ganglionic core. J Comp Neurol 234:168-181.

Skinner K (1985b) The structure of the fourth abdominal ganglion of the crayfish, Procambarus clarkii. II. Synaptic neuropils. J Comp Neurol 234:182-191.

Stangier J, Hilbich C, Dircksen H, Keller R (1988) Distribution of a novel cardioactive peptide (CCAP) in the nervous system of the shore crab Carcinus maenas. Peptides 9:795-800.

Stein PSG (1971) Intersegmental coordination of swimmeret motor neuron activity in crayfish. J Neurophysiol 34:310-318.

Trube A, Audehm U, Dircksen H (1994) Crustacean cardioactive peptide-immunoreactive neurons in the ventral nervous system of crayfish. J Comp Neurol 348:80-93.

Weimann JM, Skiebe P, Heinzel H-G, Soto C, Kopell N, Jorge-Rivera JC, Marder E (1997) Modulation of oscillator interactions in the crab stomatogastric ganglion by crustacean cardioactive peptide. J Neurosci 17:1748-1760.

Wiersma CAG, Hughes GM (1961) On the functional anatomy of neuronal units in the abdominal cord of the crayfish, Procambarus clarkii. J Comp Neurol 116:209-228.

Wiersma CAG, Ikeda K (1964) Interneurons commanding swimmeret movements in the crayfish, Procambarus clarkii. Comp Biochem Physiol 12:509-525. 